\title{
Yield, Quality, NPK Uptake and Monetary Returns of Fodder Maize (Zea mays L.) as Influenced by Wheat Residue Management and Fertilizer Levels
}

\author{
A.S. Patil*, A.B. Dabhi, M.S. Shitap and M.V. Sharma \\ College of Agriculture, Junagadh Agricultural University, Junagadh-362001 (Gujarat), India \\ *Corresponding author
}

\section{A B S T R A C T}

\begin{tabular}{|l|}
\hline Ke y w o r d s \\
$\begin{array}{l}\text { Residue management, } \\
\text { Fertilizer levels, Fodder } \\
\text { maize, Yield, Quality, } \\
\text { Monetary returns }\end{array}$ \\
\hline Article Info \\
$\begin{array}{l}\text { Accepted: } \\
\text { 20 August } 2018 \\
\text { Available Online: } \\
\text { 10 September } 2018\end{array}$ \\
\hline
\end{tabular}

Introduction

Maize (Zea mays L.) also fondly called as a "king of fodder" due to its great importance in animal diet, as it can be grown throughout the year mainly due to its photo-thermoinsensitive character. Maize is cultivated in diverse production environments ranging from temperate hill zone to the semi-arid region (Singhal, 2003).

In Saurashtra region most of the area during rabi covered by wheat crop which generated huge amount of residues interferes with cultivation practices of next crop and also affect the quality and productivity of fodder maize if it is not properly managed. The quality and productivity of fodder maize can be enhanced considerably if proper fertilizer schedules are followed. So far no systemic study involving crop residue management and fertilizer levels in fodder maize has been conducted under Saurashtra conditions. Hence, the present study was conducted to work out appropriate crop residue management practices and fertilizer levels.

\section{Materials and Methods}

A field experiment was conducted at Farming System Research Centre, AICRP-IFS, Department of Agronomy, College of 
Agriculture, Junagadh Agricultural University, Junagadh, on medium black soil during summer season of 2015 and 2016 to study the effect of wheat residue management and fertilizer levels on fodder maize (Zea mays L.) in medium black soils of Saurashtra. The experiment was laid out in Split Plot Design (SPD) with fifteen treatment combinations and three replications. Treatment comprised of five residue management practices $\left(R_{1}\right)$ no residue incorporation (Manual harvesting), $\left(\mathrm{R}_{2}\right)$ harvesting through combine harvester and burning the straw, $\left(\mathrm{R}_{3}\right)$ harvesting through combine harvester and straw incorporation in soil, $\left(\mathrm{R}_{4}\right)$ harvesting through combine harvester and straw incorporation in soil $+5 \mathrm{~kg}$ T. viride $+25 \mathrm{~kg} \mathrm{~N} \mathrm{ha}^{-1}$ and $\left(\mathrm{R}_{5}\right)$ harvesting through combine harvester and straw incorporation in soil $+5 \mathrm{~kg}$ madhyam $+25 \mathrm{~kg}$ $\mathrm{N}$ ha $^{-1}$ assigned to main plot and three fertilizer levels as a sub plot treatments viz., $\left(\mathrm{F}_{1}\right)$ control, $\left(\mathrm{F}_{2}\right)$ 50\% RDF and $\left(\mathrm{F}_{3}\right) \quad 100 \%$ RDF. Crude protein content of fodder was calculated by multiplying the nitrogen content with a factor 6.25 as proposed by Tsen and Martin (1971) and expressed in terms of per cent protein content. Estimation of nitrogen was done by micro Kjeldhal's method. Phosphorus content in the fodder was determined by Venedomolybdo phosphoric yellow colour method using spectrophotometer and potassium concentration in fodder by Flame photometer method employing the methods given by Jackson (1974). The net plot wise yield was recorded and subjected to statistical analysis Cochran and Cox (1957).

\section{Results and Discussion}

\section{Effect of wheat residue management}

The data depicted in Table 1 showed that harvesting through combine harvester and straw incorporation in soil $+5 \mathrm{~kg}$ madhyam + $25 \mathrm{~kg} \mathrm{~N} \mathrm{ha}^{-1}\left(\mathrm{R}_{5}\right)$ recorded significantly higher fodder yield (54057 $\left.\mathrm{kg} \mathrm{ha}{ }^{-1}\right)$ but it was remained at par with $\mathrm{R}_{4}$ (harvesting through combine harvester and straw incorporation in soil $+5 \mathrm{~kg} T$. viride $+25 \mathrm{~kg} \mathrm{~N} \mathrm{ha}^{-1}$ ). This might be due to, yield of crop is a function of several yield components which are dependent on complimentary interaction between vegetative and reproductive growth of crop. A significant increase in green fodder yield under these treatments because, straw incorporation with microbial inoculants leads to faster decomposition of straw, improved the status of soil organic matter, leading to higher uptake of available nutrients from soil and ultimately increased the growth and yield components. The results are in accordance with the results obtained by Singh and Yadav (2006) and Rajkhowa and Borah (2008).

Data presented in Table 1 indicated that significantly higher protein content $(7.03 \%)$ were reported in treatment $\mathrm{R}_{5}$ (harvesting through combine harvester and straw incorporation in soil $+5 \mathrm{~kg}$ madhyam $+25 \mathrm{~kg}$ $\mathrm{N} \mathrm{ha}^{-1}$ ) as compared to rest of the treatments except $\mathrm{R}_{4}$ (harvesting through combine harvester and straw incorporation in soil $+5 \mathrm{~kg}$ T. viride $+25 \mathrm{~kg} \mathrm{~N} \mathrm{ha}^{-1}$ ).

This might be due to increased $\mathrm{N}$ content in fodder which might be the results of increased availability of nitrogen to plant. Higher nitrogen content is directly responsible for higher protein because it is a primary component of amino acid which constitutes the basis of protein (Soleymani et al., 2016). In case of fiber content (Table 1) different residue management practices does not influence their significant effect.

Further data presented in Table 1 indicated that treatment $R_{5}$ (harvesting through combine harvester and straw incorporation in soil +5 $\mathrm{kg}$ madhyam $+25 \mathrm{~kg} \mathrm{~N} \mathrm{ha}{ }^{-1}$ ) registered significantly higher $\mathrm{N}, \mathrm{P}$ and $\mathrm{K}$ uptake of $60.62,12.68$ and $59.55 \mathrm{~kg} \mathrm{ha}^{-1}$ respectively, 
which was remained on same line with harvesting through combine harvester and straw incorporation in soil $+5 \mathrm{~kg} \mathrm{~T}$. viride + $25 \mathrm{~kg} \mathrm{~N} \mathrm{ha}^{-1}\left(\mathrm{R}_{4}\right)$ this is because the nutrient uptake is a function of yield and nutrient concentration in plant.

Thus significant improvement in uptake of $\mathrm{N}$, $\mathrm{P}$ and $\mathrm{K}$ might be attributed to their concentration in fodder and associated with higher fodder yield.

This might also attributed to decomposition of straw inoculated with microorganism may release soluble nutrients chelating compounds, which may improve nutrient uptake Kachroo and Dixit (2005), Yadav et al., (2009) and Pandiaraj et al., (2015).

Treatment $\mathrm{R}_{5}$ (harvesting through combine harvester and straw incorporation in soil +5 $\mathrm{kg}$ madhyam $+25 \mathrm{~kg} \mathrm{~N}^{-1}$ ) recorded the highest net realization of ₹ $45029 \mathrm{ha}^{-1}$ with BCR 3.27 followed by treatment $R_{4}$ (harvesting through combine harvester and straw incorporation in soil $+5 \mathrm{~kg} T$. viride + $25 \mathrm{~kg} \mathrm{~N} \mathrm{ha}^{-1}$ ) with net realization of ₹41855 $\mathrm{ha}^{-1}$ and BCR of 3.12.

\section{Effect of fertilizer levels}

Result revealed in (Table 1) showed that significantly highest fodder $\left(53200 \mathrm{~kg} \mathrm{ha}^{-1}\right)$ was recorded under treatment $\mathrm{F}_{3}(100 \% \mathrm{RDF})$ over rest of the levels. This may probably attributed to NPK being part of the essential nutrients required for the promotion of the meristematic and physiological activities such root development, plant dry matter production leading to an efficient absorption and translocation of water and nutrients, interception of solar radiation and assimilation of carbon dioxide. These activities promote higher photosynthetic activities leading to the production of enough assimilates for subsequent translocation towards sink and hence the production of higher yield. These findings closely associated with those of Jalia et al., (2008) and Maqsood and Shehzad (2013).

Application of $100 \%$ RDF $\left(\mathrm{F}_{3}\right)$ recorded significantly highest protein content $(6.80 \%)$ over rest of the levels (Table 1). The probable reason behind that higher $\mathrm{N}$ content in fodder and subsequently higher $\mathrm{N}$ uptake by fodder that supports to enhance protein content under the effect. This could also be explained on the basis of increase in crude protein content was due to fact that $\mathrm{P}$ is an important structural component of DNA and RNA. The phosphate group in nucleic acid bridges the RNA or DNA. DNA is the carrier of genetic information and RNAs functions in protein synthesis these findings are in close agreement with the findings of Almodares et al., (2009), Rashid and Iqbal (2012) and Kanduri et al., (2016). In case of fiber content (Table 1) different fertilizer levels does not influence their significant effect.

It is evident from the data that (Table 1) application of $100 \%$ RDF $\left(\mathrm{F}_{3}\right)$ registered significantly highest $\mathrm{N}, \mathrm{P}$ and $\mathrm{K}$ uptake by fodder of $58.24,11.90$ and $58.34 \mathrm{~kg} \mathrm{ha}^{-1}$ respectively.

Thus, significant improvement in uptake of $\mathrm{N}$, $\mathrm{P}$ and $\mathrm{K}$ might be attributed to their respective higher concentration in fodder and associated with higher fodder yield. This might also be attributed to better availability of nutrient in the soil under these treatments Paramasivan et al., (2010), Rashid and Iqbal (2012) and Enjueke (2013).

Data presented in Table 1 indicated that, treatments $\mathrm{F}_{3} \quad(100 \% \quad \mathrm{RDF})$ recorded maximum net realization of ₹ 43021 ha $^{-1}$ along with $\mathrm{BCR}$ value 3.13. Minimum net realization ( $₹ 30836 \mathrm{ha}^{-1}$ ) with BCR (2.81) was recorded in treatment $\mathrm{F}_{1}$ (control). 
Table.1 Effect of wheat residue management and fertilizer levels of yield, protein content, NPK uptake, net returns and BCR

\begin{tabular}{|c|c|c|c|c|c|c|c|c|}
\hline Treatments & $\begin{array}{c}\text { Fodder } \\
\text { yield } \\
\left(\mathrm{kg} \mathrm{ha}^{-1}\right)\end{array}$ & $\begin{array}{l}\text { Protein } \\
\text { content }(\%)\end{array}$ & $\begin{array}{c}\text { Fiber } \\
\text { content (\%) }\end{array}$ & $\begin{array}{l}\text { N uptake } \\
\left(\mathrm{kg} \mathrm{ha}^{-1}\right)\end{array}$ & $\begin{array}{l}\text { P uptake } \\
\left(\mathrm{kg} \mathrm{ha}^{-1}\right)\end{array}$ & $\begin{array}{l}\text { K uptake } \\
\left(\mathrm{kg} \mathrm{ha}^{-1}\right)\end{array}$ & $\begin{array}{l}\text { Net returns } \\
\qquad \text { ha }^{-1}\end{array}$ & B:C ratio \\
\hline & \multicolumn{8}{|c|}{ Main plot (Crop residue management: $\mathbf{R}$ ) } \\
\hline $\mathbf{R}_{1}$ & 39936 & 5.72 & 22.85 & 36.77 & 7.01 & 39.07 & 28673 & 2.49 \\
\hline$\overline{\mathbf{R}_{2}}$ & 37620 & 5.56 & 22.39 & 33.69 & 6.50 & 35.82 & 26567 & 2.43 \\
\hline $\mathbf{R}_{\mathbf{3}}$ & 45625 & 5.99 & 23.04 & 44.34 & 8.82 & 46.65 & 35900 & 2.86 \\
\hline $\mathbf{R}_{4}$ & 51366 & 6.88 & 23.41 & 57.10 & 11.74 & 55.77 & 41855 & 3.12 \\
\hline $\mathbf{R}_{\mathbf{5}}$ & 54057 & 7.03 & 23.45 & 60.62 & 12.68 & 59.55 & 45029 & 3.27 \\
\hline S.Em \pm & 1288 & 0.11 & 0.36 & 1.59 & 0.45 & 1.89 & - & - \\
\hline C. D. at 5\% & 3860 & 0.34 & NS & 5.08 & 1.34 & 5.67 & - & - \\
\hline \multirow[t]{2}{*}{ C.V. $(\%)$} & 12 & 7.61 & 6.58 & 15.46 & 16.31 & 16.95 & - & - \\
\hline & \multicolumn{8}{|c|}{ Sub plot (Fertilizer levels: F) } \\
\hline $\mathbf{F}_{1}$ & 39668 & 5.62 & 22.64 & 36.01 & 6.93 & 38.28 & 30836 & 2.81 \\
\hline $\mathrm{F}_{2}$ & 44294 & 6.28 & 23.16 & 45.25 & 9.22 & 45.49 & 34552 & 2.86 \\
\hline $\mathrm{F}_{3}$ & 53200 & 6.80 & 23.29 & 58.24 & 11.90 & 58.34 & 43021 & 3.13 \\
\hline S.Em \pm & 534 & 0.08 & 0.21 & 0.99 & 0.26 & 0.86 & - & - \\
\hline C. D. at $5 \%$ & 1526 & 0.24 & NS & 2.84 & 0.75 & 2.45 & - & - \\
\hline C.V. $(\%)$ & 8 & 7.35 & 5.01 & 11.70 & 13.40 & 9.91 & - & - \\
\hline $\begin{array}{c}\text { Interaction } \\
(\mathbf{R} \times \mathbf{F})\end{array}$ & Sig. & NS & NS & Sig. & Sig. & Sig. & - & - \\
\hline
\end{tabular}

$\mathrm{R}_{1}$ : No residue incorporation (Manual harvesting); $\mathrm{R}_{2}$ :Harvesting through combine harvester and burning the straw; $\mathrm{R}_{3}$ :Harvesting through combine harvester and straw incorporation in soil; $\mathrm{R}_{4}$ : Harvesting through combine harvester and straw incorporation in soil $+5 \mathrm{~kg}$ T. viride $+25 \mathrm{~kg} \mathrm{~N}^{-1}$; $\mathrm{R}_{5}:$ harvesting through combine harvester and straw incorporation in soil $+5 \mathrm{~kg}$ madhyam $+25 \mathrm{~kg} \mathrm{~N}^{-1}$

$\mathrm{F}_{1}$ : Control; $\mathrm{F}_{2}: 50 \% \mathrm{RDF} ; \mathrm{F}_{3}: 100 \% \mathrm{RDF}$ 
Table.2 Interaction effect of wheat residue management and fertilizer levels on Fodder yield of maize

\begin{tabular}{|c|c|c|c|c|c|}
\hline $\begin{array}{c}\text { Fertilizer } \\
\text { levels }\end{array}$ & $\mathrm{R}_{1}$ & $\mathrm{R}_{2}$ & $\mathrm{R}_{3}$ & $\mathrm{R}_{4}$ & $\mathrm{R}_{5}$ \\
\hline $\mathrm{F}_{1}$ & 35449 & 33625 & 39533 & 41827 & 47908 \\
\hline $\mathrm{F}_{2}$ & 38771 & 36432 & 41415 & 52124 & 52728 \\
\hline$F_{3}$ & 45588 & 42803 & 55927 & 60147 & 61536 \\
\hline S.Em. \pm & & & 1688 & & \\
\hline C.D. at 5 \% & & 4826 & \\
\hline C.V (\%) & \multicolumn{5}{|c}{} \\
\hline
\end{tabular}

Table.3 Interaction effect of wheat residue management and fertilizer levels on NPK uptake by fodder maize

\begin{tabular}{|c|c|c|c|c|c|}
\hline \multirow{2}{*}{$\begin{array}{l}\text { Fertilizer } \\
\text { levels }\end{array}$} & \multicolumn{5}{|c|}{ Wheat residue management } \\
\hline & $\mathbf{R}_{1}$ & $\mathbf{R}_{2}$ & $\mathbf{R}_{3}$ & $\mathbf{R}_{4}$ & $\mathbf{R}_{5}$ \\
\hline \multicolumn{6}{|c|}{ N uptake } \\
\hline $\mathbf{F}_{1}$ & 31.11 & 26.45 & 33.19 & 41.82 & 47.51 \\
\hline $\mathbf{F}_{2}$ & 35.41 & 33.03 & 40.02 & 57.11 & 60.69 \\
\hline$F_{3}$ & 43.77 & 41.59 & 59.80 & 72.38 & 73.68 \\
\hline S.Em. \pm & \multicolumn{5}{|c|}{3.14} \\
\hline C.D. at $5 \%$ & \multicolumn{5}{|c|}{8.98} \\
\hline CV (\%) & \multicolumn{5}{|c|}{11.70} \\
\hline \multicolumn{6}{|c|}{ P uptake } \\
\hline$F_{1}$ & 5.47 & 4.98 & 6.95 & 8.23 & 9.04 \\
\hline $\mathbf{F}_{2}$ & 6.90 & 6.31 & 7.56 & 12.32 & 12.99 \\
\hline$F_{3}$ & 8.66 & 8.20 & 11.96 & 14.66 & 16.00 \\
\hline S.Em. \pm & \multicolumn{5}{|c|}{0.83} \\
\hline C.D. at $5 \%$ & \multicolumn{5}{|c|}{2.38} \\
\hline CV $(\%)$ & \multicolumn{5}{|c|}{15.40} \\
\hline \multicolumn{6}{|c|}{ K uptake } \\
\hline$F_{1}$ & 33.97 & 29.12 & 37.49 & 41.72 & 49.08 \\
\hline $\mathbf{F}_{2}$ & 37.30 & 34.53 & 43.07 & 57.24 & 55.32 \\
\hline $\mathbf{F}_{3}$ & 45.95 & 43.80 & 59.38 & 68.34 & 74.25 \\
\hline S.Em. \pm & \multicolumn{5}{|c|}{2.71} \\
\hline C.D. at $5 \%$ & \multicolumn{5}{|c|}{7.74} \\
\hline CV (\%) & \multicolumn{5}{|c|}{9.91} \\
\hline
\end{tabular}

\section{Interaction effect}

The result presented in (Table: 2) revealed that treatment combination $\mathrm{R}_{5} \mathrm{~N}_{3}$ (harvesting through combine harvester and straw incorporation in soil $+5 \mathrm{~kg}$ madhyam $+25 \mathrm{~kg}$ $\mathrm{N}$ ha $^{-1}$ along with $\left.100 \% \mathrm{RDF}\right)$ registered higher fodder yield $\left(61536 \mathrm{~kg} \mathrm{ha}^{-1}\right)$ over rest of the treatment combinations but it was remained at par with $\mathrm{R}_{4} \mathrm{~N}_{3}$ (harvesting 
through combine harvester and straw incorporation in soil $+5 \mathrm{~kg} \mathrm{~T}$. viride $+25 \mathrm{~kg}$ $\mathrm{N} \mathrm{ha}^{-1}$ along with $100 \% \mathrm{RDF}$ ).

Data furnished in Table 3 showed that treatment combination $\mathrm{R}_{5} \mathrm{~F}_{3}$ (harvesting through combine harvester and straw incorporation in soil $+5 \mathrm{~kg}$ madhyam $+25 \mathrm{~kg}$ $\mathrm{N} \mathrm{ha}^{-1}+100 \% \mathrm{RDF}$ ) recorded significantly higher N, P and K uptake of 73.68, 16.00 and $74.25 \mathrm{~kg} \mathrm{ha}^{-1}$ respectively being at par with $\mathrm{R}_{4} \mathrm{~F}_{3}$ (harvesting through combine harvester and straw incorporation in soil $+5 \mathrm{~kg} T$. viride $\left.+25 \mathrm{~kg} \mathrm{~N} \mathrm{ha}^{-1}+100 \% \mathrm{RDF}\right)$.

It is inferred from the above result that improvement in yield, quality, nutrient uptake and monetary returns was observed in treatment $R_{5}$ (harvesting through combine harvester and straw incorporation in soil +5 $\mathrm{kg}$ madhyam $+25 \mathrm{~kg} \mathrm{~N} \mathrm{ha}{ }^{-1}$ ) and $\mathrm{R}_{4}$ (harvesting through combine harvester and straw incorporation in soil $+5 \mathrm{~kg} \mathrm{~T}$. viride + $25 \mathrm{~kg} \mathrm{~N} \mathrm{ha}^{-1}$ ). Nutrient supply through $100 \%$ RDF showed highest values for the same parameters.

\section{References}

Almodares, A., Jafarinia, M. and Hadi, M. R. 2009. The effect of nitrogen fertilizer on chemical compositions in corn and sweet sorghum. American-Eurasian Journal of Agriculture and Environmental Science, 6(4): 441-446.

Cochran, W. G. and Cox, G. M. 1957. Experimental Designs. $2^{\text {nd }}$ ed. Wiley, New York.

Enujeke, E. C. 2013. Nutrient content (\% dry matter) of maize as affected by different levels of fertilizers in asaba area of Delta state. Sustainable Agriculture Research, 2(3): 76-83.

Jackson, M. L. 1974. Soil Chemical Analysis, Prentice Hall of India Private.
Jaliya, M. M., Falaki, A. M., Mahmud, M. and Sani, Y. A. 2008. Effect of sowing date and NPK fertilizer rate on yield and yield components of quality protein maize (Zea mays L.). ARPN Journal of Agricultural and Biological Science, 3(2): 23-28.

Kachroo, D. and Dixit, A. K. 2005, Residue management practices using fly ash and various crop residues for productivity of rice (Oryza sativa)-wheat (Triticum aestivum) cropping system under limited moisture conditions. Indian Journal of Agronomy, 50(4): 249-252.

Kanduri, A. B., Patil, P. V. and Mogale, P. S. 2016. Green fodder yield and nutrient composition of African tall maize fodder (Zea mays) with various nitrogen-phosphorus levels. International Journal of Advanced Engineering, Management and Science, 2(5): 279-281.

Maqsood, M. and Shehzad, A. M. 2013. Optimizing nitrogen input and harvest time to maximize the maize fodder yield in Punjab, Pakistan. Pakistan Journal of Agricultural Science, 50(1): 75-81.

Pandiaraj, T., Selvaraj, S. and Ramu, N. 2015. Effect of crop residue management and nitrogen fertilizer on soil nitrogen and carbon content and productivity of wheat (Triticum aestivum L.) in two cropping systems. Journal of Agriculture Science and Technology, 17: 249-260.

Paramasivan, M., Kumaresan, K. R. and Malarvizhi, P. 2010. Effect of different levels of NPK and $\mathrm{Zn}$ on yield and nutrient uptake of hybrid maize (COHM

5) (Zea mays L.) in Mayamankuruchi (myk) series of soils of Tamil nadu. An Asian Journal of Soil Science, 5(1): 157-161.

Rajkhowa, D. J. and Borah, D. 2008. Effect of rice (Oryza sativa) straw management on growth and yield of wheat (Triticum 
aestivum). Indian Journal of Agronomy, 53(2): 112-115.

Rashid, M. and Iqbal, M. 2012. Effect of phosphorus fertilizer on yield and quality of maize (Zea mays L.) fodder on clay loam soil. The Journal of Animal and Plant Science, 22(1): 199203.

Singh, R. and Yadav, D. S. 2006. Effect of rice (Oryza sativa) residue and nitrogen on performance of wheat (Triticum aestivum) under rice- wheat cropping system. Indian Journal of Agronomy, 51(4): 247-250.

Singhal, V. 2003. Indian Agriculture. Indian Economic Data Research Centre, New Delhi.

Soleymani, A., Shahrajabian, H. M. and Khoshkharam, M. 2016. The impact of barley residue management and tillage on forage maize. Romanian Agricultural Research, 33: 161-167.

Tsen, C. C. and Martin, E. E. 1971. A note for determining protein content in various wheat flours and flour stream by kjeldhal and neutron activation methods. Cereal Chemistry, 48: 721726.

Yadav, R. L., Shukla, S. K., Suman, A. and Singh, P. N. 2009. Trichoderma inoculation and trash management effects on soil microbial biomass, soil respiration, nutrient uptake and yield of ratoon sugarcane under subtropical conditions. BiolFertil Soils, 45: 461468.

\section{How to cite this article:}

Patil, A.S., A.B. Dabhi, M.S. Shitap and Sharma, M.V. 2018. Yield, Quality, NPK Uptake and Monetary Returns of Fodder Maize (Zea mays L.) as Influenced by Wheat Residue Management and Fertilizer Levels. Int.J.Curr.Microbiol.App.Sci. 7(09): 3119-3125. doi: https://doi.org/10.20546/ijcmas.2018.709.388 